\title{
A contribution to the knowledge of the chironomid fauna (Diptera) in southern Portugal
}

\author{
J. Malo 1 \\ M. Morais 1 \\ P. Pinto ${ }^{1}$
}

Keywords : Diptera, Chironomidae, faunal list, temporary streams, Portugal.

For the first time, a faunal list of 89 species of Chironomidae is presented for the South of Portugal, using data from drift samples taken in 12 rivers and streams. 35 species of Chironomidae are new for Portugal. The more important biogeographic result is the appearance of various mediterranean species -as Paramerina spec. Griechenland, Tanytarsus Pe23 Langton 1991 and Virgatanytarsus albisutus-; this last specie was not previously known from the Iberian Peninsula.

\section{Contribution à la connaissance des Chironomidés (Diptera) du sud du Portugal}

Mots clés : Diptera, Chironomidae, faunistique, rivières temporaires, Portugal.

Pour la première fois, une liste de 89 espèces de Chironomidae récoltés par dérive dans 12 rivières du Sud du Portugal est présentée. 35 espèces sont nouvelles pour le Portugal. Les récoltes les plus intéressantes concernent plusieurs espèces méditerranéennes - Paramerina spec. Griechenland, Tanytarsus Pe 23 Langton 1991 et Virgatanytarsus albisutus-; cette dernière espèce n'était pas connue de la Péninsule Ibérique.

\section{Introduction}

A species inventory for a geographic region in which such data is limited, constitutes a basic phase in biogeographic and ecological research (Cranston 1995). There are few previous studies on the Chironomid of Portugal. The first and, until now, only species list for Portugal was published by Reiss (1989) based on a study mainly dealing with Chironomidae in northern and central regions but also including samples from one site on the Guadiana River in southern Portugal. The present study was undertaken to add to knowledge of distribution of the Chironomidae in this latter region, thereby complementing data from the north and central zones, and to provide the first chironomid faunal list for southern Portugal.

1. Departament of Biology. University of Evora. Apt.94. 7001Evora Codex, Portugal.

\section{Study area}

This study has been carried out in the South of Portugal (Fig.1), in the Mediterranean region as defined by Rivas-Martinez \& Armaiz (1984). The study area, which includes the large hydrographic basin of the Guadiana River as well as three smaller catchments (Sorraia, Sado and Mira), extends from Tejo river in the north southwards to the Algarve.

Twelve sited were selected : four on the main tributaries of the Guadiana River (Xévora, Degebe, Ardila and Vascão); three on tributaries of the Sado River (Valverde, Alcáçovas and Xarrama) as well as one on the main channel; three on tributaries in the Sorraia basin (Seda, Sousal and Divor) and one on the main channel of the Mira River (Fig.1). Some of the streams from which samples were obtained are temporary. The Valverde stream dries in early summer and remains dry until the autumn. The Sousel, Alcáçovas, Degebe and Vascão streams reduce to isolated pools. Three collecting sites were located near reservoir. Sites on Seda 


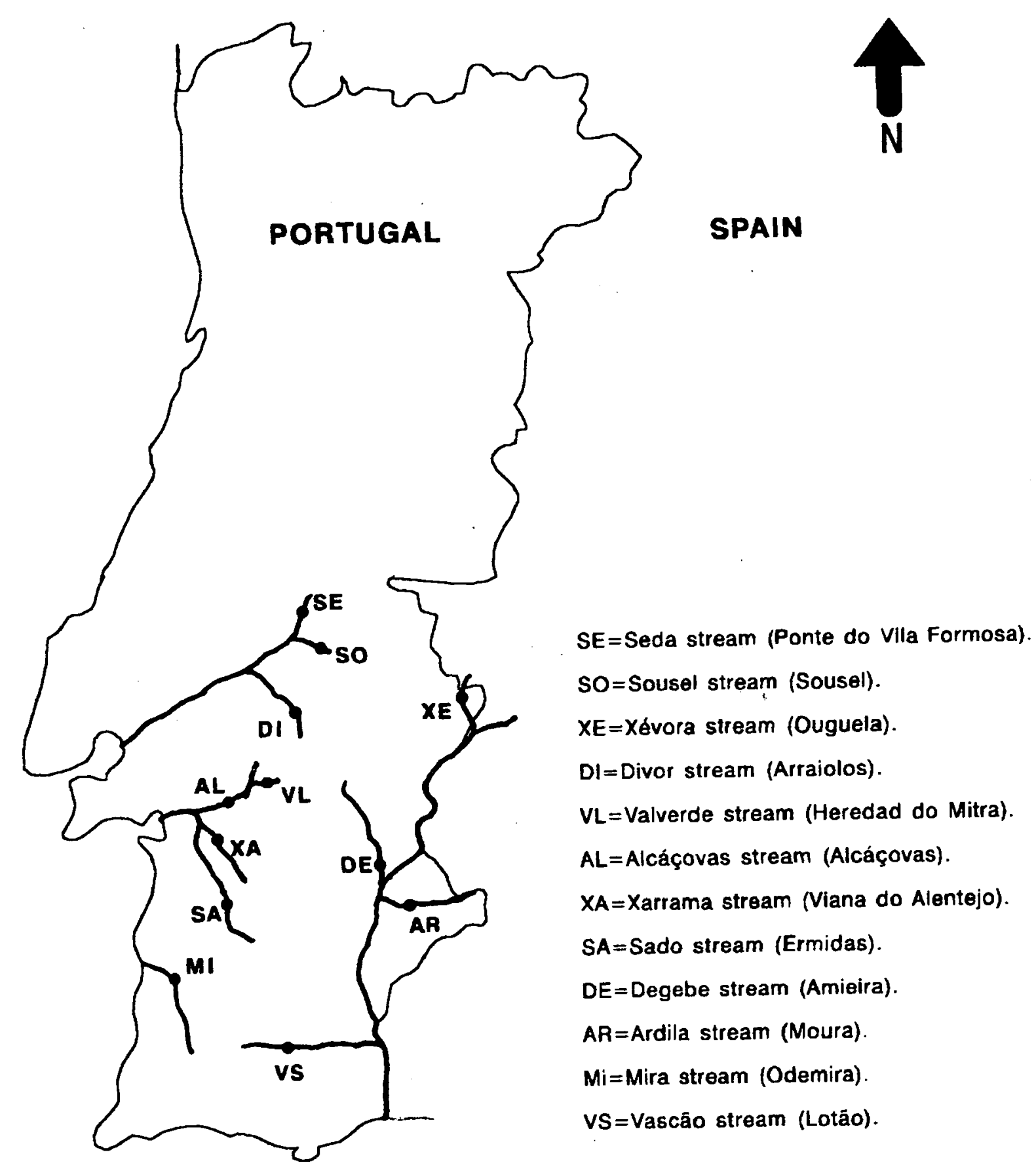

Fig. 1. Location and identification of the 125 collecting sites.

Fig. 1. Emplacements des 12 stations de récoltes.

and Alcáçovas streams lie at the beginning of a reservoir while the site on the Divor stream was situated downstream of a dam.

\section{Material and methods}

Drift net sampling of pupal exuviae was carried out at each site. Pupal skins were preserved and identified from Langton (1991) and Pinder \& Reiss (1986) keys. Collections were undertaken at all sites in spring (May 1996) and again in autumn (October 1996).

The flow data presented in Table 1 are the mean values achieved with longitudinal transect of depth and water velocity.

\section{Results}

Temperature and flow data for summer and autumn (Table 1) reflect the seasonal temporary characteristics of the streams by absence, or reduced flow, of water in autumn and the associated lower temperatures.

Eighty-nine (89) chironomid species were captured (Table 2). The sub-family Chironominae was dominant with 45 species with approximately similar representation by the tribes Chironomini -25 species (28.2\%) - and the Tanytarsini -22 species (24.7\%). Thirty (30) species of Orthocladiinae ( $33.7 \%$ ) were recorded followed by the Tanypodinae with 10 species $(11.2 \%)$, and one species (1) each in the Diamesinae 
Table 1. Flow and temperature of the 12 collecting sites during date samples.

Tableau 1. Débrits et températures des 12 stations aux dates de récoltées.

\begin{tabular}{llcccc}
\hline & & \multicolumn{2}{c}{ Flow $\left(\mathrm{m}^{3} / \mathrm{sec}\right)$} & \multicolumn{2}{c}{ Temperature $\left({ }^{\circ} \mathrm{C}\right)$} \\
Stream- & Basin & May-96 & October-96 & May-96 & October-96 \\
\hline Xévora & Guadiana & 1.15 & 0.51 & 26.2 & 21.3 \\
Degebe & Guadiana & 0.53 & 0 & 28.4 & 15.1 \\
Ardila & Guadiana & 1.79 & 0.65 & 29.4 & 19.1 \\
Vascão & Guadiana & 0.49 & 0 & 29.6 & 18.1 \\
Seda & Tejo & 1.18 & 0.39 & 23.4 & 14.3 \\
Sousel & Tejo & 0.35 & 0 & 25.4 & 15.2 \\
Divor & Tejo & 0.43 & 0.29 & 23.2 & 18.3 \\
Valverde & Sado & 0.15 & 0 & 28.4 & 19.2 \\
Alcáçovas & Sado & 0.27 & 0 & 27.8 & 19.3 \\
Xarrama & Sado & 0.37 & 0.11 & 26.2 & 18.4 \\
Sado & Sado & 0.88 & 0.32 & 25.9 & 16.5 \\
Mira & Mira & 2.18 & 0.67 & 24.2 & 17.8 \\
\hline
\end{tabular}

$(1.1 \%)$ and Prodiamesinae $(1.1 \%)$. In comparison with the previous faunal list (Reiss 1989) 35 species are recorded for the first time for Portugal.

The most common species were Rheocricotopus (Psilocricotopus) atripes (recorded from 11 sites), Cricotopus bicinctus (9 sites), Cardiocladius fuscus (6 sites), Thienemanniella clavicornis (6 sites) and Cladotanytarsus atridorsum ( 6 sites). A lower number of chironomid species was detected in the seasonal streams with more temporary characteristics. Nine (9) species were recorded from the Alcáçovas stream, 11 from the Sousel and Degebe streams, 12 from the Vascão stream and 13 in Valverde stream.

\section{Discussion}

Some similarity is evident when comparing results with the chironomid fauna of neighbouring countries. $85.3 \%$ of the species found are also known in Spanish fauna (Cobo et al. 1987, Soriano et al. 1993), $56.2 \%$ in Morocco (Azzouzi \& Laville 1987, Azzouzi et al. 1988), $30.3 \%$ in Tunisia (Boumaiza \& Laville 1988) and $61.9 \%$ in the North Africa (Morocco, Tunisia or Algeria). Microchironomus tener, Polypedilum nubifer, Paratanytarsus bituberculatus and Paratanytarsus confusus previously recorded in North Africa and Spain (Ashe \& Cranston 1990), were captured for the first time in Portugal. Virgatanytarsus albisutus, previously known from North Africa (Morocco and Algeria) and the Canary Islands (Cranston \& Armitage 1988, Laville \& Reiss 1992) is recorded from the Iberian Peninsula for the first time. Rheocricotopus (Psilocricotopus) atripes and Cladotanytarsus atridorsum although common in Spain (Cobo et al. 1987) are recorded for the first time in Portugal.

\section{Comments on some species :}

- Paramerina spec. Griechenland Fittkau, is a mediterranean species (Laville \& Reiss 1992) recorded in Greece, Italy and Spain. This species, typical of running water (Langton 1991), was only collected in spring, in the small Valverde stream.

- Dicrotendipes peringueyanus Kieffer, a characteristic species of stagnant and slow-moving water (Langton 1991) and which has a predominant afrotropical distribution (Azzouzi et al. 1992), is also recorded from neighbouring countries bordering the Mediterranean (Spain, France, Italy, Algeria, Morocco). It was collected in the Seda stream (influenced by reservoir) and in the Xarrama, Sado and Ardila streams, during the period of more accentuated lenitic characteristics-

- Microtendipes chloris (Meigen);-is typical of stagnant water and lives in littoral and sublittoral zones (Pinder \& Reiss 1986). It was recently recorded from the Iberian Peninsula (Soriano et al. 1993) and in this study was obtained in streams influenced by reservoirs (Seda and Divor streams) and the Valverde stream.

- Paratanytarsus bituberculatus (Edwards), a species characteristic of stagnant water (Langton 1991) was found in the slow-flowing waters of the Xarrama stream in the autumn collections.

- Virgatanytarsus albisutus (Santos-Abreu), cited previously from Morocco and Algeria (Laville \& Reiss 1992) and the Canary Islands (Cranston \& Armitage 1988) has a widespread distribution in the Seda, Xévora, Valverde, Xarrama and Ardila streams.

- Rheocricotopus (Psilocricotopus) atripes (Kieffer), a typical denizen of streams (Langton 1991) was the 
Table 2. List and sampling sites for chironomids. * Species new to Portugal.

Tableau 2. Liste des chironomidés récoltés dans les stations d'échantillonnages. * Espèces nouvelles pour le Portugal.

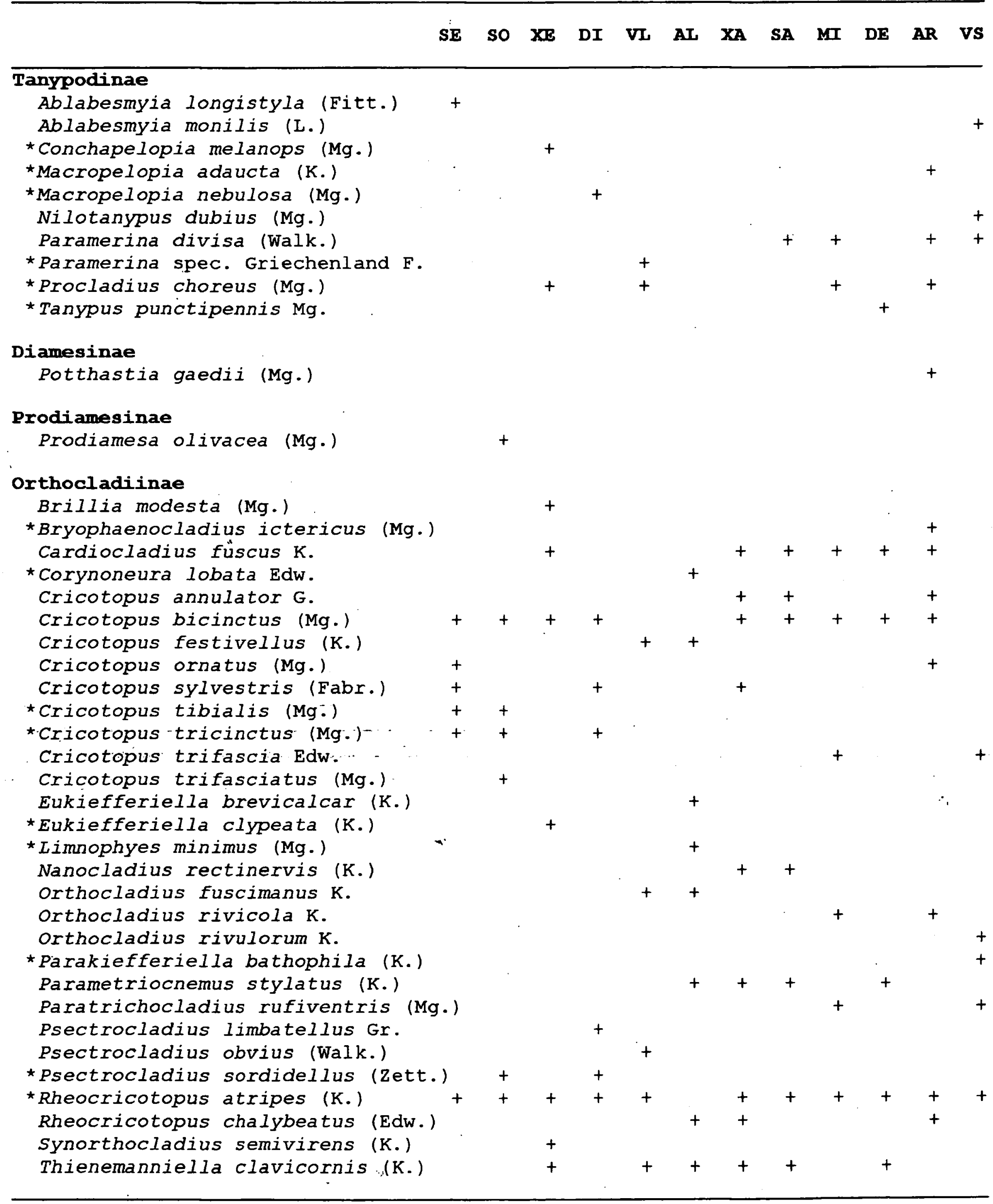


Table 2 (continued). List and sampling sites for chironomids. * Species new to Portugal.

Tableau 2 (suite). Liste des chironomidés récoltés dans les stations d'échantillonnages: ${ }^{*}$ Espèces nouvelles pour le Portugal.

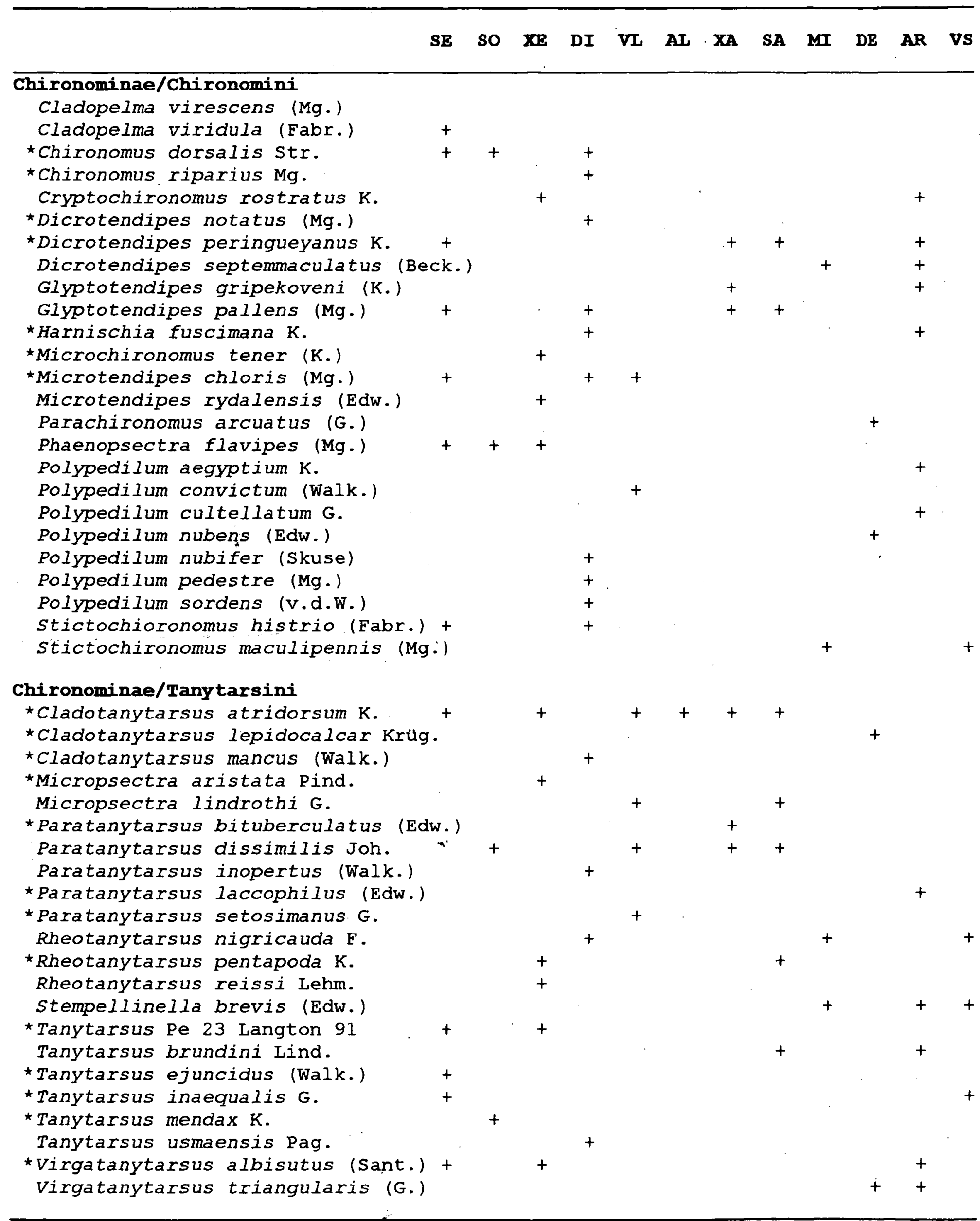


most abundant species obtained in the collections but was absent from samples taken in the Alcáçovas stream.

\section{Acknowledgments}

The authors greatfully acknowledge a grant from the State Science and Technical Research Office, Education and Science Ministry, Spain. They are grateful to Dr. Declan Murray (Ireland) for reading and improving the first manuscript.

\section{References}

Ashe P. \& Cranston P.S. 1990. - Chironomidae, in Soos A. \& Papp L. (eds.). Catalogue of Palearctic Diptera. Volume 2. Akademiai Kiado, Budapest and Elsevier Science, Amsterdam : 113-355.

Azzouzi A. \& Laville H. 1987. - Premier inventaire faunistique des Chironomidés (Diptera) du Maroc. Annls. Limnol., 23 (3) : 217 224.

Azzouzi A.; Laville H. \& Reiss F. 1992. - Nouvelles récoltes de Chironomidés (Diptera) du Maroc. Annls. Limnol., 28 (3) : 225232.

Boumaiza M. \& Laville H. 1988. - Premier inventaire faunistique des Chironomidés (Diptera : Chironomidae) des eaux courantes de Tunisie. Annls. Limnol., 24 (2) : 173-181.
Cobo F., Jimenez M., Casas J., Vilchez A., Soriano O., Sevillano M., Rieradevall M. Muñoz I. \& Prat N. 1987. - Inventario faunístico de los Quironómidos conocidos de la Península Ibérica. Alquibla : 56-65.

Cranston P.S. 1995. - Biogeography, in Armitage P.D., Cranston P.S. \& Pinder L.C.V. (eds.). Chironomidae : Biology and ecology of non-biting midges. Chapman \& Hall, London : 62-84.

Cranston P.S. \& Armitage P.D. 1988. - The Canary Islands Chironomidae described by T. Becker and by Santos Abreu. Dtsch. ent. Z., N.F. 35 (4-5) : 341-354.

Langton P.H. 1991. - A key to pupal exuviae of West Palearctic Chironomidae. Privately, published : Huntington, England : $386 \mathrm{p}$.

Laville H. \& Reiss F. 1992. - The chironomid fauna in the mediterranean region reviewed. Netherlands Journal of Aquatic Ecology, $26(2-4): 239-245$.

Pinder L.C.V. \& Reiss F. 1986. - The pupae of Chironominae (Diptera : Chironomidae) of the Holarctic region (Keys and diagnoses). Ent. scand. Suppl., $28: 299-471$.

Reiss F. 1989. - Erster Beitrag zur Chironomidenfauna Portugals. NachrBl. bayer. Ent., 38 (2) : 46-50.

Rivas-Martinez S. \& Armariz C. 1984. - Bioclimatology and vegetation in Iberian Penninsula. Bull. Soc. Bot. Fr., 131 : 111-120.

Soriano O., Ramil J. \& Cobo F. 1993. - Adiciones a la fauna ibérica de Quironómidos (Diptera : Chironomidae). Graellsia, 49 : 97 103. 